\title{
Sociocultural and legal aspects of the education-related migration in Russia
}

\author{
Natalia Filimonova ${ }^{1, *}$, Elena Romanyuk $^{1}$, Aleksey Godenko ${ }^{1}$, and Marina Davydova ${ }^{2}$ \\ ${ }^{1}$ Volgograd State Technical University, Faculty for Foreign Students' Training, Chair of Russian language, 28, Lenin av., 400005, \\ Volgograd, Russia \\ ${ }^{2}$ Volgograd State University The Law Institute, Chair of constitutional and municipal law, 100, Universitetskiy av., 400062, Volgograd, \\ Russia
}

\begin{abstract}
In this article, the prospects of the implementation of the new State migration policy framework of the Russian Federation for 2019-2025 as applied to student migrants are analyzed. We have studied the educational process for foreign students at all levels of higher education as a part of education-related (study-related) migration. We have defined the following three aspects: social, cultural, and legal as equivalent factors of adaptation and socialization for foreign students. We highlight that apart from the basic learning competencies, it is crucial to develop skills for communicating in the language of the host country while acknowledging the basic values of the social and cultural realia that are new for foreign students. The teacher has a significant role in the organization of the education process for foreign students. We have studied the stages of students' adaptation and integration into the new sociocultural and academic environment. The hypothesis is that it is crucial to learn and take into account national and psychological characteristics of student migrants from around the world. We provide examples based on the research results of the adaptation analysis of Volgograd State Technical University foreign students. We also provide recommendations for the organization of the education process and communication with foreign students.
\end{abstract}

\section{Introduction}

In the 21 st century, migration is going global. In Russia, migratory flows have grown significantly. On the one hand, they lead to numerous social, economic, and political problems. On the other hand, they are a vital social and economic source for the Russian economy as well as a positive factor in the country's foreign policy. In Russia, as well as in other European countries, there is a firm demographic crisis with both a decline in fertility and population aging. As well as any other country, Russia has its peculiarities. Russia is a vast country with variegated natural and climatic conditions, and its regions differ from one another in their social and economic development. Another peculiarity is the sociocultural proximity of Russians with the descendants from the former republics of the Soviet Union, and a lot of them live, work, or study in Russia.

Migration is any geographical movement by people with a view to change their permanent address or temporary residence for education or labor reasons. A migrant (from Latin migrantis - the one who moves) is a person who migrates and crosses the state's border. The migrants' integration into the new community is a factor of the state's successful migration policy. There is an influx of labor migrants, also there are many student migrants in our country. The latter can be divided into several groups. The first and largest group is comprised of foreign students of colleges and universities who live in Russia for an extended period of time far from their families and who return home after graduation. The second group is comprised of the children of the labor migrants, temporarily displaced persons, and refugees; they are students of schools, colleges, and universities who live in Russia with their families. The third group is comprised of the labor migrants who follow courses or study in TVETs, colleges, and universities in part-time or distance learning.

This article is concerned with the members of the first group, namely, the foreign students of universities. The issues of the education-related, or study-related, migration are studied by Androsova D. N., Arefiev A. L., Andreev A. J., Dmitriev M. M., Larin A. G., Kosheleva E. Y., Ryazantsev S. V., Pismennaya E. V., Samofalova E. I., Shevchenko A. V., Sheregy F. E., and others.

The research objective is to study the major aspects of education-related migration and its features in the modern world. In this study, we have used theoretical and empirical methods. The main theoretical methods are the literature and legislation review in the sphere of education-related migration. The main empirical methods are questionnaire and statistical data analysis.

In terms of terminology, we can assume that 'education-related' and 'study-related' migration is really close in meaning. However, some researchers

\footnotetext{
* Corresponding author: filimonova_n@rambler.ru
} 
distinguish one from the other and apply the former term only to those migrants who get higher education [1].

Not only is studying the education-related migration important in theory, but also in practice since it can help raise Russia's status in the world arena. In recent years, the number of foreign students studying in Russian universities has been growing. To cite statistics, the number of foreign students in Russian universities has almost doubled in the past ten years while the number of Russian students has nearly halved over the same time period. Another noteworthy point is that the percentage of foreign students in all Russian universities had increased from $2,36 \%$ to $7,11 \%$ in $2009-2017$ [2].

\section{Aspects of education-related migration in Russia}

\subsection{Education-related migration in Russia and the USSR}

Before the 1917 Revolution, the education-related migration had mainly been external: Russian students studied in European countries, namely, Germany and France. After the Revolution, the internal migration started to develop. Since the education was free, there were great numbers of foreigners in Russia while the policy of the new state was aimed at improving the external relations. According to the Order №273 of the Council of Labor and Defense of 06.08.1921" On foreign students of Higher Technical Educational Institutions", foreign students had equal rights with Russian students which guaranteed access to free education, dormitory, scholarship, and employment opportunities after graduation [3]. Later, in the 1930s, the enhancement of the internal education-related migration nearly stopped due to political reasons. It was only after the Second World War when the influx of foreign students started to grow again. According to statistics, in 1950, there were only 5900 foreign students in the USSR which is $5,4 \%$ out of the total percentage of student migrants in the world [4]. However, in the 1950-1960s, the number of student migrants grew significantly and the first preparatory faculty for foreign students was open in MSU and RUDN was founded which was the leading university in the USSR which specialized in educating foreigners. In VSTU, the first foreigners applied in 1962 and the preparatory faculty was founded in 1973. By the end of the 1980s, there were approximately 180000 student migrants in the USSR and that accounted for $13 \%$ of the world percentage [5]. However, in the 1990s, the selection and education system for teaching foreigners in the country's universities was nearly destroyed. From the beginning of the 2000s the system has been rebuilt with certain changes. Now, the vast majority of foreign students pay tuition fee or the sending state pays for them on the grounds that they will work in government structures after graduation. Now, students from the countries of the former Soviet Union, the so-called 'near abroad', are regarded to as foreign students and many of them study in the Russian universities. The world's educational institutions compete with one another in attracting foreign students. That is why Russia's authorities create special organizations in the field of education service export, such as Rossotrudnichestvo, the Russian language centers and Russian culture centers in different countries, and Internet resources [6], [7].

\subsection{Legal aspects of the education-related migration in Russia}

Migration policy as a prioritized area in a state's affairs is a complex of variegated elements. On the one hand, it is a policy which is aimed at attracting migrants as well as creating beneficial legal and economic conditions for their integration and adaptation to the Russian community. On the other hand, it is the nation's law enforcement policy: fighting illegal migration and crimes committed by the migrants and against them.

The policy of legal stimulation of intellectual migration is a special concern. It implies creating additional legal assurance for qualified employees who will help counterbalance, if not stop, the skills drain from Russia.

Alongside labor migration of qualified staff, education-related migration is a crucial part of intellectual migration. Education-related migration is a traditional source of "foreigners integrated to the community who can be viewed as future highly-qualified potential Russian citizens" [8].

It can be assumed that the Russian policy for attracting student migrants is rather successful. Over 2000-2016, the number of foreign students in the Russian universities had tripled (from 58992 to 162286 , respectively) [9]. Nevertheless, these numbers cannot be compared to those of foreign countries. According to the WTO, the world education market is estimated at \$50-60 $\mathrm{mln}$. The USA is its sustainable leader that controls nearly a third of the world financial education turnover and earns on foreign students 15 times more than the US Government spends on the whole education system. Education is the fifth important export category in the American economy [10].

Now we will consider the ways which may help increase the competitiveness of the Russian education system in the global market.

The Constitution and the Russian legislation guarantee the right to education as it is stated in the international acts. Every person's right to education is acknowledged. Primary and secondary education should be free, technical and vocational should be available for everyone. Foreigners should have access to education as all Russian citizens.

The real number of educational rights of foreign students differs from those of the Russians'. Besides, the educational status of non-citizens is not homogenous, there are groups of people with additional rights:

- Persons who receive education in terms of the quota set by the Russian Government [11];

- Compatriots who live abroad (the Federal Law "On education in the Russian Federation");

- Refugees (the Federal Law “On refugees”); 
- The citizens of states that Russia has international agreements with which imply an extended set of rights in education (the Agreement "On providing equal rights for educational institutions admission for the citizens of state parties of the Contract on improving the integration in economic and humanitarian spheres of 29.03.1996).

The main normative legal acts that determine the legal status of foreign students who receive education in Russia are the Federal Law of 25.07.2002 № 115-FL (reviewed 01.05.2019) "On the legal status of the foreigners in the Russian Federation" and the Federal Law of 15.08.1996 № 114-FL (reviewed 01.05.2019) "On the procedures for exit from and entry into the Russian Federation".

Researchers have noticed that there is a liberalization tendency in the legislation in terms of education-related migration [12]. Since 2014 the citizenship of the Russian Federation can be obtained under a simplified procedure if meeting certain conditions, for example, receiving vocational education in Russia (the Federal Law "On the citizenship of the Russian Federation"). Also, the procedure for changing the education program was simplified. Since 2017 it is possible to extend the period of temporary stay without leaving Russia for foreigners who are students of a preparatory faculty (the Federal Law "On the legal status of foreigners in the Russian Federation").

Nevertheless, there is still a great number of administrative barriers that can be eliminated. Particularly, the possibility to combine working and learning makes education more attractive. There is such an opportunity for foreign students, though limited (during holidays only or in the business units of the institution) [13]. The possibility to combine working and learning would foster the adaptation of foreign students and develop their professional skills. Despite the fact that researchers have raised this issue, lawmakers do not seem eager to change the current state of affairs. Also, there are other suggestions: facilitating recruitment after graduation, obtaining a residence or citizenship permit.

There are two more groups of factors that influence the education-related migration flow:

1. The quality of education, in particular, the acceptation of it in the sending country. This obstacle can be overcome by signing international agreements on higher education between the two countries;

2. The standard of living in the host country, safetylevel, as well as security against crimes xenophobically motivated. The law enforcement agencies should be responsible for tackling this issue.

Thus, the juridical regulation of education-related migration is a complex process. The objectives mentioned in the documents for strategic planning (Decree of the President of the Russian Federation "On the State migration policy framework of the Russian Federation for 2019-2025") can be reached only by a systematic approach to solving different problems that influence the attractiveness of the Russian higher education. This will help turn education into the government's participation instrument in globalization processesand into a crucial source of government revenue.

"Those who engage in education export gain three times: they do not spend resources on the childhood of the future applicants; they earn by providing education services; and, finally, they get the youth already integrated into the hostcommunity" [14].

\subsection{Social aspects of education-related migration in Russia}

For a few years, the student migrants studying in the Russian universities have to live in the foreign-language sociocultural community. Here, the problem is that "they are socialized adults who had their identity formed in the environment in which they grew up. Usually, they have their own views on life, attitudes, and the system of values" [15].

Each of them has to go through sociopsychological, sociocultural, and academic adaptation. The success of this process depends on several factors:

- the comfort/discomfort of living in the dormitory (during the first year in the host country, the wellbeing of students depends heavily on whether the conditions in a dormitory suit their habits and needs) as well as obstacles in communicating with people from different countries on a daily basis;

- the remoteness of the dormitory from the campuses, transport and/or city center;

- the lack of communication with students of other nationalities (due to language-related obstacles and the lack of cross-cultural communication skills);

- the possibility/lack of possibility to communicate with the Russian students and Russian citizens (for the majority of foreign students such communication is on low levels during the whole period of education);

- the lack of awareness of the Russian history and culture as well as the word courtesy;

- the lack of communication with the Russian teachers and the lack of help (freshmen students face this problem since they are used to the help from the teachers in the preparatory courses);

-the quality of the infrastructure in the university (modern classrooms, computer classes, language laboratories, libraries, etc.);

- the proper organization of the learning process and availability of course materials, etc.

The questionnaires (a quantitative research method) help understand how severe the aforementioned problems are. Thus, the following questionnaire (a part of it is presented) has helped us learn more about the student migrants studying in VSTU:

1. State the reason why you came to study in Russia:

a. The high quality of education.

b. The tuition fee is lower than in Western countries.

c. My relatives study here.

d. It is safer here, I could not continue living in my homeland.

e. Other (say why).

2. What language do you speak in Russia?

a. Mostly Russian. 
b. Both the native language and the Russian language.

c. I use my native language more often than Russian.

d. Other (say why).

3. What source do you use to learn the news in the world and your country?

a. The Internet.

b. Radio, TV.

c. Newspapers and magazines.

d. Other people.

e. Other (what source?).

4. What problems have you faced while studying in Russia?:

a. Paperwork.

b. Receiving medical care.

c. Academic problems.

d. Communication problems.

e. Financial hardship.

f. Other (what problems?).

5. What don't you like in Russia?:

a. Household issues.

b. Infrastructure.

c. Russians' attitude.

d. Education system.

e. Relationships with other students.

f. Other (say what).

It should be mentioned that the range of questions offered to students to answer does not really differ among the Russian universities, that is why it is not enough to examine the quantitative results in one particular university. As Drozzhina D. S. has stated, it is important to combine different approaches and compare the data obtained through different research in order to "get a more comprehensive presentation of the students' adaptation which is necessary for the further implementation of measures to manage this process" [16]. However, it is not enough to simply have an idea of how student migrants feel in the new sociocultural environment and what factors influence the success of their sociopsychological, sociocultural, and academic adaptation. It is crucial to find out what measures should be taken in order to facilitate adaptation to the new environment. One of the suggested measures is the psychological follow-up for foreign students in Russian universities. According to Titova O. I., this system will provide psychological diagnostics, psychological education that will include "role playing communication with the Russian students, workers, and citizens with whom foreign students communicate on a daily basis," psychological prevention as well as psychological guidance which is important for "helping create new social attitudes and personal decision making" [17]. Unfortunately, providing psychological follow-up is rare in Russian universities. Teachers-practitioners have to rely on the realia common for the majority of the universities. Socialization of student migrants is based on getting acquainted with the new social and cultural realia and on the further adaptation. The primary socialization takes place within a person's inner circle (family, friends, neighbors, acquaintances) and depends on cultural and national traditions, social, political, and economic conditions of the homeland. The secondary socialization deals with adaptation to the new social and cultural environment. In Russia, some scientists do not consider the secondary socialization to be a process of complete integration of a person into the social system (Parsons T., Merton R.). It is more about the sociopsychological adaptation to the study group, faculty, dormitory, the closest society (shops, banks, drugstores, post offices, cinemas, etc.). the secondary socialization of student migrants affects all aspects of their life in Russia creating the basics of the crosscultural communication. The rapid acknowledgment with the new social, cultural, and language environment is not possible without learning the Russian language. $50 \%$ of the learning time during the first year is dedicated to learning Russian. Due to the fact that there is a small number of Russian universities with the courses taught in English, learning Russian is of the highest priority for foreign students. It is also one of the greatest obstacles. Underdeveloped language skills prevent foreign students from social communication and expanding their social circle. It is important to promote communication between Russian and foreign students in order to develop cross-cultural communication skills as well as foster tolerance [18] and communication skills. It is suggested to hold literary workshops and competitions commemorating the Russian poets and writers, sports events, to celebrate national holidays, to encourage events and vacations where foreign and Russian students spend time together. The properly organized extracurricular activities can help reduce the language barrier, enhance communication skills in different life situations, develop independence, initiative as well as facilitate the adaptation to the sociocultural environment.

\subsection{The cultural aspects of education-related migration in Russia}

The competitiveness of the university depends on creating a favorable multicultural environment. A teacher and a foreign student can be regarded as subjects of interpersonal, intercultural, and international communication. It is important to ensure these types of communication at all levels of education. The preparatory level is assumed to be the most complicated due to the clash of cultures (this level takes place in other countries as well) [19]. Everything the foreign students face is new for them: the climate, household, academic environment, communication with people from different countries who study at an international faculty. Going through this level is a stressful process which can lead to a culture shock described in numerous works. Entering a new sociocultural environment is a difficult and somewhat painful process for every foreign student in spite of the proximity of the education systems of the sending and host countries, the proximity of cultures, and the time dedicated to learning Russian. A new sociocultural environment is not an abstract notion, it is a new world for the foreign students which often differs from the one they are used to. Moreover, sometimes foreign students romanticize the Russian realia and react negatively when facing them. 
In this aspect, the main thesis seems to be equality of all cultures in communication. No culture is better or worse, all are equal. Only this approach can prevent conflicts in cross-cultural communication. In this aspect, communication is not only an exchange of information but the process of getting to know each other while accepting the differences. According to the founder of the intercultural communication theory, Edward Hall, we should teach both the language and the culture to foreign students. The scientist stated that the sign system of the language accounts for only $20 \%$, while $80 \%$ is nonverbal communication [20]. That is why one should be aware of the nonverbal communication patterns of different countries: intonation, facial expressions, gestures, touching, distance. This knowledge helps foreign students in cross-cultural communication. The American anthropologist Milton Bennet introduced the notion of the Developmental Model of Intercultural Sensitivity that consists of three stages from ethnocentrism to accepting the culture of others [21]. Foreign students go through all these stages. Not only do they apply to learning Russian, but also to social and culture studies, history, philosophy, and other courses. Cross-cultural communication can be regarded as the ability of foreign students to communicate with people from different cultures in Russian while accepting the values of the new sociocultural environment [22]. Richard Lewis, a wellknown British social theorist, developed a culture classification which can help in working with student migrants. He defined culture as a behavioral model and classified all cultures into Linear-Active, Multi-Active, and Re-Active [23]. The vast majority of student migrants in Russia are from Multi-Active or Re-Active cultures. That is why teachers should bear in mind that the students from the former group are emotional, talkative, and unpunctual. On the other hand, the students from the latter group are silent, punctual, respectful but cannot speak their my mind directly. Teachers should teach both the language and communication behavior.

The aforementioned scientists classified cultures into monochronic and polychronic according to their attitudes to time. This aspect should also be appreciated since some students can fail to manage their studying time.

We can state that the possibility offered to foreign students to present their own culture is really beneficial [24]. Culture is a product of collective activity but it is possible to teach communication styles to students and adapt their mind to the new sociocultural environment. In spite of globalization, it is impossible to unite all cultures into one. However, it is possible to study them and accept their differences. Student migrants gain the new identity under enculturation. Here, it is important to note that the native culture becomes visible only when confronted with another one. Student migrants should try their best to gain knowledge about the host culture and learn how to change the behavior so that it will suit the new sociocultural environment. The teacher's role is to facilitate this process.

\section{Conclusion}

\subsection{Part one}

1. The intellectual migration should be stimulated through legislation as it is one of the sources for the economic development of Russia.

2. Foreign students should have equal rights to education with Russian students.

3. There is a liberalization tendency in legislation in terms of education-related migration.

4. The possibility to combine work and education can serve as an incentive for the student migrants.

5. The education-related migration flow depends on two factors: the acceptation of the quality of education in the sending country and the safety in the host country.

6. The juridical regulation of the education-related migration is complex, so the existing problems should be dealt in aggregate.

\subsection{Part two}

1. There are several objectives in the field of educationrelated migration. Namely, creating a favorable social environment for living and adaptation, accepting help from ethnocultural and religious organizations, supporting social organizations founded by student migrants (Association of foreign students in Russia, organizations of Arab, African students, etc.), promoting positive attitudes to foreign students among the citizenship.

2. We suppose that it is important to provide help and support for student migrants:

1) legal assistance (granting, registration, and application of visa; providing information on their rights and obligations; raising awareness of the Russian laws);

2) social and economic assistance for adaptation, introduction to household and education peculiarities, assistance with health examination and obtaining necessary documents;

3) psychological support (conflict prevention and resolution; support through adaptation period; moral support);

4) academic assistance which is especially important at preparatory stages as well as for interns, masters, and post-graduates.

3. Educating foreign students and employing them in Russia are beneficial for the Russian economy. Students from China, Vietnam, Korea, Syria, Iraq, Ukraine, Turkmenistan, Uzbekistan, Armenia, and Azerbaijan are eager to live in Russia and seek employment after graduation, start families, and integrate into the Russian community. The integration of student migrants happens through the education process, through language learning, and through research.

\subsection{Part three}

1. It is necessary to create a favorable multicultural environment in Russian universities. 
2. The preparatory stage of education is the most difficult period in adaptation and socialization for foreign students.

3. All cultures are equal in the communication processes. Acknowledging this helps avoid intercultural conflicts 4. Cross-cultural communication is not simply the exchange of signs, but also the process of acknowledging the cultural values of participants.

5. It is important to teach nonverbal communication patterns to foreign students.

6. Teachers should take into account cultural characteristics while teaching communication behavior to students.

7. Foreign students should have the opportunities to present their culture and traditions to the Russians.

\section{References}

1. Chinese, Vietnamese, and Mongol student migrants in the academic environment (Ed. E.J. Kosheleva, Tomsk, TPU Publisher, 2013)

2. Export of Russian educational services: Statistical Collection, Ministry of Science and Higher Education of the Russian Federation, Moscow (2018).

3. Decree of the Council of Labor and Defense. About foreign students of higher technical educational institutions, Retrieved from: http://istmat.info/node/4 6248

4. Education services export in the higher education system of the Russian Federation, Retrieved from: $\mathrm{http} / / \mathrm{www} . r u s s i a . e d u . r u /$ information/analit1300 (2006).

5. The history of educating foreign students in Russia: 1950-1990. Retrieved from:

$\mathrm{http} / /$ ru.education.mon.gov.ru/articles

6. Education in Russian for foreigners, Retrieved from: http://www.russia.edu.ru/information/

7. Education in Russian. Retrieved from: https://pushkininstitute.ru/

8. N.A. Voronina, The Institute of State and Law of The Russian Academy of Sciences, Intellectual migration: foreign and Russian regulation practices 13 (6), 173-174 (2018).

9. L.V. Andrichenko, I.V. Plyugina, Migration legislation in the Russian Federation: development tendencies and practices (INFRA-M, Moscow 2019)

10. O.D. Vykhovanets, Demoscope Weekly, Educationrelated migration as a part of Russia's migration policy 387-388, (2009). Retrieved from: http://www.demoscope.ru/weekly/2009/0387/analit0 1.php.

11. Rossiyskaya Gazeta, Order N 844 of 28.07.2014 of the Ministry of Education and Science (Ed. 17.03.2015) On approving the regulations governing the selection of foreigners for quot a education stated by the Government of the Russian Federation $\mathbf{2 8 7}$ (17.12.2014) (2014).
12. L.V. Andrichenko, I.V. Plyugina, Migration legislation in the Russian Federation: development tendencies and practices (INFRA-M, Moscow, 2019).

13. Rossiyskaya Gazeta, The Federal Law On the juridical status of foreigners in the Russian Federation 140 (31.07.2002) (2002)

14. O.D.Vykhovanets, Demoscope Weekly, Educationrelated migration as a part of Russia's migration policy 387-388, (2009), Retrieved from: http://www.demoscope.ru/weekly/2009/0387/analit0 1.php

15. M.A. Ivanova, Sociopsychological adaptation of foreign students to the Russian higher education, (Doctoral dissertation, Saint-Petersburg, 2001

16. D.S. Drozzhina, Empirical studies, Universitas, Studying adaptation of foreign students: discussion of methodology 1( 3), 33-47 (2013)

17. O.I. Titova, KSPU Vestnik, Psychological assistance of foreign students and its role in providing highquality education in multicultural environment 1(14), 98-102 (2015)

18. Ai, Xin, Advances in Social Science, Education and Humanities Research: Proceedings of the 2017 3rd International Conference on Social Science and Higher Education, The Enlightenment of Internationalization of Higher Education on Foreign Language Education Retrieved from: https://doi.org/10.2991/icsshe-17.2017.48 (2017)

19. Deni Adi Wijaya, Djono and dan Suryo Ediyono, Global Conference on Teaching, Assessment, and Learning in Education, The Attitude of socioharmony and Local Wisdom: an Indicator of the Development of Social Tolerance of High School Students $\quad 42, \quad$ Retrieved from: https://doi.org/10.1051/shsconf/20184200049//SHS (2018)

20. E. Hall, The Silent Language (New York, Doublebay, 1959)

21. Milton J. Bennett, Basic Concepts of Intercultural Communication (Selected Readings, Yarmouth, 1998)

22. N.Ju. Filimonova, E.S. Romanyuk, Intercultural communication in the conditions of international faculty (VSTU, Volgograd, 2015).

23. Richard D. Lewis, When Cultures Collide: managing successfully across cultures (Rev. ed., Nicolas Brealey Publishing, 2003)

24. N.Ju. Filimonova, E.S. Romanyuk, A.E. Godenko, O. Ergunova, International Conference on the Theory and Practice of Personality Formation in Modern Society, Cross-Cultural Communication in PreUniversity Training of Foreign Students 198, 260265 Retrieved from: https://doi.org/10.2991/ictppfms-18.2018.46 (2018) 